
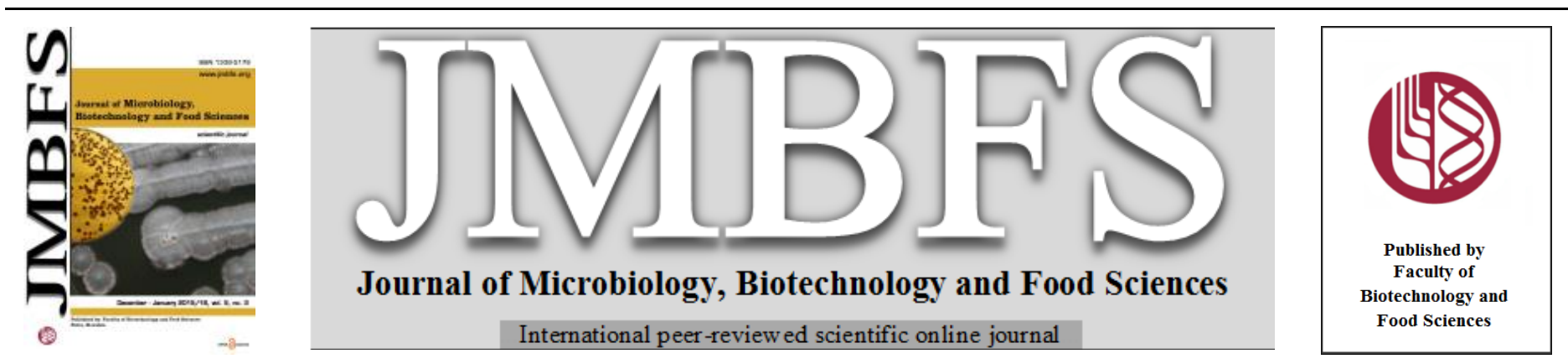

\title{
INVESTIGATION OF HYDROCARBON BIO-REMOVAL BY THE INDIGENOUS BACTERIA ISOLATED FROM CRUDE OIL CONTAMINATED SOILS
}

\author{
Farhad Gilavand ${ }^{l}$, Abdolrazagh Marzban ${ }^{1,2}$, Gholamhossein Ebrahimipour ${ }^{1}$, Maryam Karkhane ${ }^{2}$
}

Address(es): Abdolrazagh Marzban,

${ }^{1}$ Department of Microbiology, Faculty of Biological Sciences, Shahid Beheshti University, Tehran, Iran.

${ }^{2}$ Gastroenterology and Liver Diseases Research Center, Shahid Beheshti University of Medical sciences, Tehran, Iran.

*Corresponding author: Marzban86@mail.com

doi: 10.15414/jmbfs.2015/16.5.3.212-215

\section{ARTICLE INFO}

Received 15. 4. 2014

Revised 17. 1. 2015

Accepted 31. 8. 2015

Published 1. 12. 2015

Regular article open $\partial_{\text {ACCESS }}$

\section{ABSTRACT}

The current study reports hydrocarbon degrading capacity of two bacterial strains isolated from soils contaminated by crude oil. Two indigenous bacterial strains (Bs1 and Bs2) were isolated from polluted soils around oil reservoirs, Ahvaz, Iran. Their abilities to degrade different hydrocarbons, including olive oil, crude oil and coal tar were investigated, using measuring total organic carbon (TOC) supplemented as sole carbon source in the mineral medium. To identify bacterial isolates, morphology and biochemical characteristics along with $16 \mathrm{~S}$ rDNA analysis were considered. The results showed strain Bs1 was able to consume more than $34 \%$ of coal tar, $61 \%$ of crude oil, and $81 \%$ of olive oil during 14 days incubation. The hydrocarbon degrading ability of Bs 2 was 24,39 , and $68 \%$ in the presence of coal tar, crude oil and olive oil, respectively as sole carbon source. Additionally, their mixed culture of two isolates led to a $5 \%$ increase in their biodegradation effectiveness. The subsequent morphological and biochemical characterization and phylogenetic analyses showed the close relationship of Bs1 and Bs2 (about 98 and 99\%) to Pseudomonas aeruginosa strains of CMG581 and BM8, respectively.

Keywords: Bioremediation, Biodegradatin, Pseudomonas, Crude oil, Coal tar

\section{INTRODUCTION}

The petroleum industry is the backbone of Iran economy, recognizes it as one of the few countries with a huge amount of underground oil reservoirs. Hence, activities relating with oil exploration, refining and transportation give rise to spillage and accumulation of large amounts of crude oil and other petroleum contaminants on the marine and terrestrial environments (Hassanshahian et al. 2012; Zolfaghari-Baghbaderani et al., 2012). Additionally, the unpredictable repercussions of oil pollutants, impact of these hazardous wastes on human health is complicated due to their incomplete decomposition to harmless end products, acquiring toxic, carcinogenic potentials (Sathishkumar et al., 2008).

Considering the detrimental impact of oil hydrocarbons on the living aspects of ecosystems, a global worry has risen not only among environmental protection organizations, but also among the whole population (Silva-Castro et al., 2013; Zolfaghari-Baghbaderani et al. , 2012). This issue urges oil associated industrial companies to develop clean technologies, and eco-friendly strategies highlighting the bioremediation. The bioremediation is defined as the use of microorganisms to eliminate environmental contaminants from water and soil, through the complete degradation of different hydrocarbons into carbon dioxide and water or conversion of them to harmless byproducts. However, it is pointed out that oil contaminated areas contains a wide variety of structurally different compounds, with supportive or otherwise effect on the local micro-flora, depending on their individual concentrations and nature (Das and Chandran, 2011). The oily sludge is a very complicated recalcitrant residue, composed of different oils, fats, solids, organic compounds and metals. There is structurally a large diversity among organic compounds, from simplest readily degradable forms such as short-chain linear alkanes (known as aliphatics) to most complex and less-degradable ones with one or more cyclic rings (aromatics) like cycloalkanes, benzene, toluene, xylenes, phenols, and at the top, polycyclic aromatic hydrocarbons (Bamforth and Singleton, 2005; Xu and Obbard, 2004). Regarding the very complex structure of some oily sludge constituents, the synergistic interactions among the member of the micro-flora associations has been demonstrated and favored over pure cultures in bioaugmentation strategy (Alvarez et al., 2011; Domde et al., 2007; Maqbool et al., 2012). The present paper aims to study the degradation capacity of the two most efficient isolates, including Bs1 and Bs2, which were investigated in pure and mix form inoculation to mineral media supplemented with different organic hydrocarbons.

\section{MATERIAL AND METHODS}

Culture medium

Nutrient agar (Oxoid) and mineral media compositions from Merck, Germany were exploited for respective bacterial enrichment and experimental steps. The mineral medium consisted of the following constituents: $\mathrm{NH}_{4} \mathrm{Cl}(1.95 \mathrm{~g} / 1) ; \mathrm{NaCl}$ $(0.85 \mathrm{~g} / \mathrm{l}) ; \mathrm{Na}_{2} \mathrm{HPO}_{4}(0.24 \mathrm{~g} / \mathrm{l}) ; \mathrm{KCl}(0.05 \mathrm{~g} / \mathrm{l}) ; \mathrm{MgSO}_{4}(0.01 \mathrm{~g} / \mathrm{l}) ;$ Calcium chloride $\mathrm{CaCl}_{2}(0.01 \mathrm{~g} / \mathrm{l}) ; \mathrm{FeSO}_{4}(0.01 \mathrm{~g} / \mathrm{l})$; and trace elements (Monteiro et al., 2009).

\section{Sample collection and bacterial isolation}

The oily sludge and soil samples were collected from oil exploration sites desert areas around Ahvaz, south of Iran; and transferred to laboratory in sterile bottles. To isolate the bacterial community, $10 \mathrm{~g}$ of soil samples were mixed with $100 \mathrm{ml}$ aseptic distilled water in $250 \mathrm{ml}$ flasks and then shaken at $100 \mathrm{rpm}$ for $10 \mathrm{~min}$. After sedimentation of the soils, supernatants were serially diluted from $10^{-1}$ to $10^{-10}$. Of each serial dilution, $100 \mu \mathrm{l}$ was streaked on nutrient agar plates by an L-shape glass rod. All the plates then, were incubated at $32{ }^{\circ} \mathrm{C}$ for $72 \mathrm{~h}$. The colonies appeared on agar plates were tested to possess ability to hydrocarbon degradation through culturing on $100 \mathrm{ml}$ mineral media supplemented with 500 $\mathrm{mg}$ of either crude oil or coal tar as the sole carbon and energy source. Culture conditions for first step were adjusted as temperature $32{ }^{\circ} \mathrm{C}, \mathrm{pH} 8$ and orbital shaking $100 \mathrm{rpm}$ for two weeks incubation period.

\section{Optimization of biodegrading efficiency}

To assay biodegradability of the respective hydrocarbons of coal tar, crude oil and olive oil, $100 \mathrm{ml}$ of mineral medium in the $250 \mathrm{ml}$ flasks containing $500 \mathrm{mg}$ of each hydrocarbon, was prepared. Subsequently, $1 \mathrm{ml}$ of each isolate, separately and both as co-culture with the turbidity of $0.5 \mathrm{McFarland}\left(1.5 \times 10^{8}\right.$ cells $/ \mathrm{ml}$ ) were added to the flasks as initial inoculums. The control prepared with the equal conditions, consider for the bacterial experiments, but without initial inoculum. Simultaneously, all the flasks were incubated at $32{ }^{\circ} \mathrm{C}$ for two weeks on orbital shaker with $100 \mathrm{rpm}$. All of the experiments were performed in triplicate. 


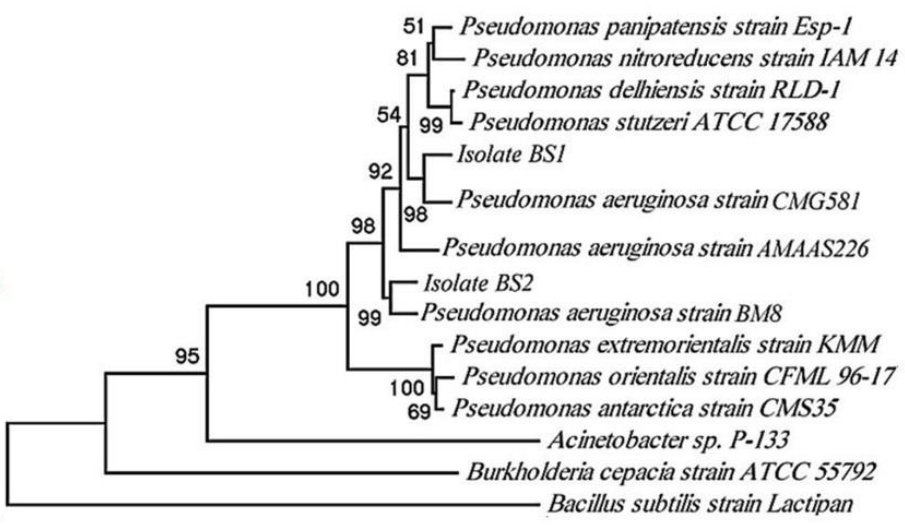

Figure 1 Phylogenetic neighbor-joining tree based on the 16S rDNA gene sequence alignment of our bacterial strains with Pseudomonas aeruginosa CMG581 and BM8 as well as others. Bootstrap values (1000 replicates) are shown as percentages at each node.

\section{Biomass production and substrate reduction assessment}

Figures of 2, 3 and 4 show the TOC removal capacity of the single isolates and their mix culture within 14 days. In general, the TOC reduction in the liquid media culture which inoculated with $\mathrm{Bs} 1, \mathrm{Bs} 2$ and their co-culture, is highest for olive oil supplemented media, while it diminishes for crude oil and then coal tar supplements in the efficiency order. As Figure 4 shown, up to $80 \%$ of olive oil was consumed by the both Bs1 and Bs 2 during less than 10 days incubation, concomitant of ascending the biomass value until it reached a stationary phase. However, percent removal of TOC for the media supplemented with coal tar and crude oil decreases when the respective Bs2, Bs1 and their mixture cultivations were used.
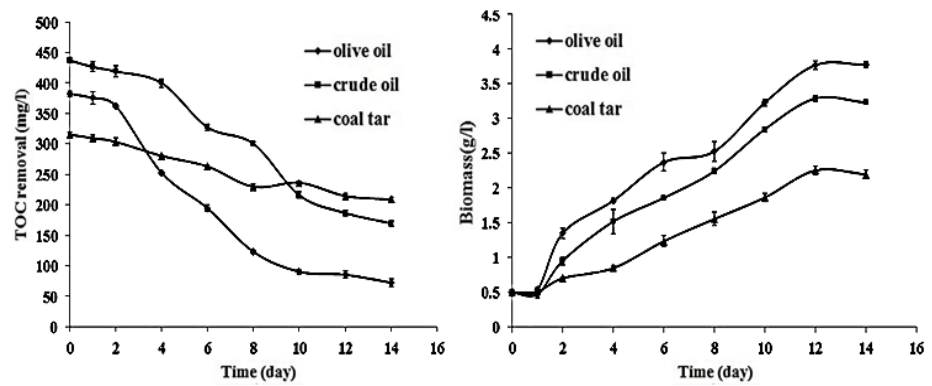

Figure 2 Biomass production (right) and TOC removal profiles (left ) for Bs1 isolate
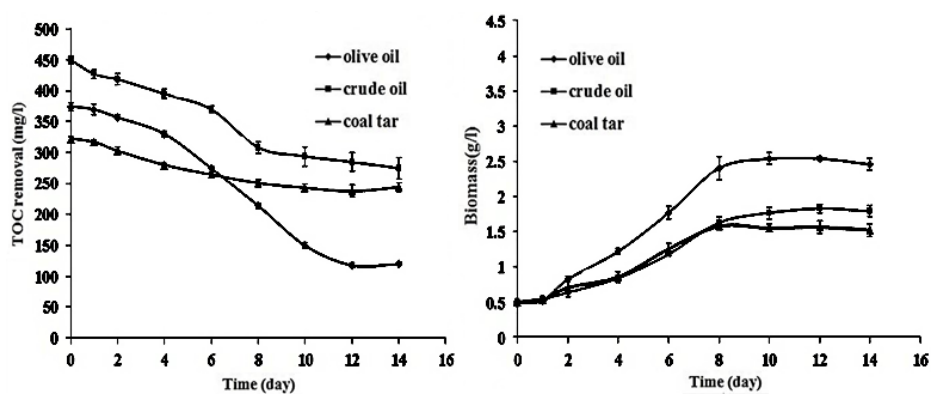

Figure 3 Biomass production (right) and TOC removal profiles (left ) for Bs2 isolate
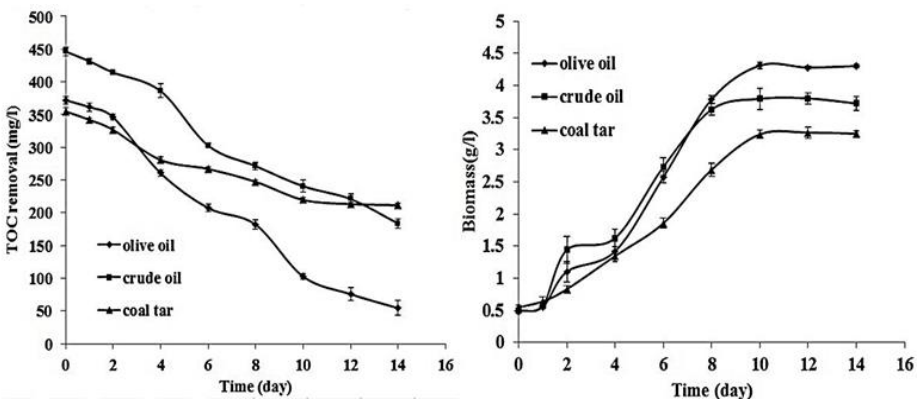

Figure 4 Biomass production (right) and TOC removal profiles (left ) for coculture of Bs1 and Bs2 isolates 
There are many reports in the literature regarding the highly effective potential of members of Pseudomonas genus to degrade various hydrocarbon pollutants, including aliphatic, aromatic and polycyclic aromatic compounds in various environments, from marine ecosystem with strict condition to those with very unsteady harsh climates such as salterns and even extreme environment (Emtiazi et al., 2005; Enontiemonria et al., 2012; Silva et al., 2006). Their ubiquitous presence in almost every environment is reasonable cause that they possess strong enzymatic pathways involve in the metabolism of various hazardous materials such as compounds derived from petroleum or organic pesticides. However, the excess spillage of petroleum products in the environment led to be exhausted metabolic capacity of microorganisms and ultimately accumulation of hydrocarbons with toxicity and carcinogenicity, which raised concern over their hazardous problems to both human and ecosystem (Plaza et al., 2005; Voll et al., 1978). Therefore, it is both economically and environmentally necessary to screen these sites in the hope of finding single microorganism or compatible consortia with the greater degradation capacity to eliminate the contaminated locals. Our data showed that 5 to $10 \%$ increase in hydrocarbon biodegradability when Bs1 and Bs2 are employed as mixed culture (Arulazhagan et al, 2010). Many reports that contribution of bacteria involve in hydrocarbon compounds have approved (Daane et al, 2001; Shahriari et al, 2014).

The use of microbial consortia may result in metabolic complementary, as metabolites produced through partial degradation by a specific microorganism can be utilized as carbon source by other organisms, increasing the chance for complete elimination of hydrocarbons from the environment (de Morais and Tauk-Tornisielo, 2009; Joint et al., 2010; Sathishkumar et al. , 2008; Singh and Fulekar, 2007). This is especially more significantly necessary to eliminate pollutants with more complex compounds, e.g. polycyclic aromatic compounds $(\mathrm{PAH})$, than those are with linear aliphatic structure (in our case, olive oil), since the metabolic pathways for PAHs are too long and complicated thus, needs numerous enzymes and several metabolic pathways, to be accommodated in single organism (Alquati et al., 2005; Arulazhagan and Vasudevan, 2009). On the other hand, it is probable that some species remove the toxic metabolites of the preceding species, which might otherwise hamper microbial activity (Das and Chandran, 2011; Peixoto et al., 2011).

\section{CONCLUSION}

Overall, it can be suitable to enrich these strains through fermentation for bioaugmentation and/or adjust the chemical composition of their pollutant sites by addition of some bulk useless compounds from other activities, to optimize the condition for their growth, together with increase in the local decontamination. Usage of their bulk mixture with high catabolic capacity is favored over other strains with the equivalent or even higher biodegradation potential for following reasons: these strains were attained from the local, that is, their native habitats, meaning higher adaptation with the given environmental condition. They would readily be survive and grow in the locals more efficiently without any conditional or little adjustment. After all, they are more easily accessible than other strains for bioremediation in Ahvaz, Iran.

Acknowledgments: This research was performed at Microbiology laboratory, Faculty of Biological Sciences, Shahid Beheshti University in Tehran as a part of environmental research project concerning in situ bioremediation by management of Professor Gholamhossein Ebrahimipour.

\section{REFERENCES}

ALQUATI, C., PAPACCHINI, M., RICCARDI, C., SPICAGLIA, S. BESTETTI, G. 2005. Diversity of naphthalene-degrading bacteria from a petroleum contaminated soil. Annals of Microbiology, 55, 237-242.

ALVAREZ, V.M., MARQUES, J.M., KORENBLUM, E., SELDIN, L. 2011. Comparative Bioremediation of Crude Oil-Amended Tropical Soil Microcosms by Natural Attenuation, Bioaugmentation, or Bioenrichment. Applied and Environmental Soil Science, 2011, 1-10. http://dx.doi.org/10.1155/2011/156320 ARULAZHAGAN, P., VASUDEVAN, N. 2009. Role of a moderately halophilic bacterial consortium in the biodegradation of polyaromatic hydrocarbons. Marine Pollutution Bulletin,

58 ,

256-62.

http://dx.doi.org/10.1016/j.marpolbul.2008.09.017

ARULAZHAGAN, P., VASUDEVAN, N.,Yeom, T. 2010. Biodegradation of polycyclic aromatic hydrocarbon by a halotolerant bacterial consortium isolated from marine environment. International Journal of Science and Technology, 7 (4), 639-665. http://dx.doi.org/10.1007/BF03326174

BAMFORTH, S.M., SINGLETON, I. 2005. Bioremediation of polycyclic aromatic hydrocarbons: current knowledge and future directions. Journal of Chemical Technology \& Biotechnology, 80, 723-736. http://dx.doi.org/ $10.1002 /$ jctb. 1276

DAANE, L.L., HARJONO, I., ZYLSTRA, G.J., HAGGBLOM, M.M. 2001 Isolation and Characterization of Polycyclic Aromatic Hydrocarbon-Degrading Bacteria Associated with the Rhizosphere of Salt Marsh Plants. Applied and
Environmental Microbiology,

2683-2691 http://dx.doi.org/10.1128/AEM.67.6.2683-2691

DAS, N., CHANDRAN, P. 2011. Microbial Degradation of Petroleum Hydrocarbon Contaminants: An Overview. Biotechnology Research International, 1-13. http://dx.doi.org/10.4061/2011/941810

DE MORAIS, E.B., TAUK-TORNISIELO, S.M. 2009. Biodegradation of Oil Refinery Residues Using Mixed-Culture of Microorganisms Isolated from a Landfarming. Brazilian Archives of Biology and Technology, 52, 1571-1578. http://dx.doi.org/10.1590/S1516-89132009000600029

DOMDE, P., KAPLEY, A., PUROHIT, H.J. 2007. Impact of bioaugmentation with a consortium of bacteria on the remediation of wastewater-containing hydrocarbons. Environmental of Science Pollution Research International, 14, 7 11. http://dx.doi.org/10.1065/espr2006.11.358

EMTIAZI, G., SHAKARAMI, H., NAHVI, I., MIRDAMADIAN, S.H. 2005 Utilization of petroleum hydrocarbons by Pseudomonas sp and transformed Escherichia coli. African Journal of Biotechnology, 4, 172-176.

ENONTIEMONRIA, E.V., KOFI, H.F., CYBIL, O., GBENGA, T. 2012. The Effects o f Pseudomonas Aeroginosa and Aspergillus Niger o $n$ the Bioremediation of Raw a nd Treated Crude Oil Polluted Water. International Journal of Science and Technology, 2, 345-352.

HASSANSHAHIAN, M., TEBYANIAN, H., CAPPELLO, S. 2012. Isolation and characterization of two crude oil-degrading yeast strains, Yarrowia lipolytica PG20 and PG-32, from the Persian Gulf. Marine Pollutution Bulletin, 64, 13861391. http://dx.doi.org/ 10.1016/j.marpolbul.2012.04.020.

HOLT, J.G., KRIEG, N.R., SNEATHM, P.H.A., STALEY, J.T., WILLIAMS, S.T. 1994. Bergey's Manual of Determinative Bacteriology, 9thedn. Baltimore, MD: Williams and Williams.

JOINT, I., MÜHLING, M., QUERELLOU, J. 2010. Culturing marine bacteria an essential prerequisite for biodiscovery. Journal of Microbiology and Biotechnology, $\quad 3, \quad 564-575 . \quad \mathrm{http} / / \mathrm{dx} . \mathrm{doi} .0 \mathrm{rg} / 10.1111 / \mathrm{j} .1751$ 7915.2010.00188.x

MAQBOOL, F., WANG, Z.Y., XU, Y., ZHAO, J., GAO, D.M., ZHAO, Y.G., BHATTI, Z.A., XING, B.S. 2012. Rhizodegradation of petroleum hydrocarbons by Sesbania cannabina in bioaugmented soil with free and immobilized consortium. Journal of Hazardous materials, 237, 262-269. http://dx.doi.org/10.1016/j.jhazmat.2012.08.038

MONTEIRO, A.S., COUTINHO, J.O.P.A., JÚNIOR, A.C., ROSA, C.A. SIQUEIRA, E.P., SANTOS, V.L. 2009. Characterization of new biosurfactant produced by Trichosporon montevideense CLOA 72 isolated from dairy industry effluents. Journal of Basic Microbiology, 2009, 49, 553-563.

PEIXOTO, R.S., VER MELHO, A.B., ROSADO, A.S. 2011. Petroleum Degrading Enzymes: Bioremediation and New Prospects. Enzyme Research, 2011, 1-7. http://dx.doi.org/ 10.4061/2011/475193

PLAZA, G., NALECZ-JAWECKI, G., ULFIG, K., BRIGMON, R.L. 2005 Assessment of genotoxic activity of petroleum hydrocarbon-bioremediated soil. Ecotoxicology and Environment Safety, 62, 415-20. http://dx.doi.org/ 10.1016/j.ecoenv.2004.10.014

SAMBROOK, J., FRITSCH, E.F., MANIATIS, T. 2001. Molecular cloning: laboratory manual NewYork:Cold Spring Harbor Laboratory Press.

SATHISHKUMAR, M., BINUPRIYA, A.R., BAIK, S.H., YUN, S.E. 2008 Biodegradation of crude oil by individual bacterial strains and a mixed bacterial consortium isolated from hydrocarbon contaminated areas. Clean-Soil Air Water 36, 92-96. http://dx.doi.org/10.1002/clen.200700042

SHAHRIARI, M.M., EBRAHIMIPOUR, G., ABTAHI, B., GHASSEMPOUR, A., HASHTROUDI, M.S. 2014. Biodegradation of polycyclic aromatic hydrocarbons by a bacterial consortium enriched from mangrove sediments. Journal of Environmental Health Science and Engineering 2014, 12(114), 1-9. http://dx.doi.org/10.1186/s40201-014-0114-6

SILVA, R.M.P., RODRÍGUEZ, A.Á., MONTES DE OCA, J.M.G., MORENO D.C. 2006. Biodegradation of crude oil by Pseudomonas aeruginosa AT18 STRAIN. Tecnología Química, 26, 70-77.

SILVA-CASTRO, G.A., RODELAS, B., PERUCHA, C., LAGUNA, J. GONZALEZ-LOPEZ, J., CALVO, C. 2013. Bioremediation of diesel-polluted soil using biostimulation as post-treatment after oxidation with Fenton-like reagents: Assays in a pilot plant. Science of the Total Environment, 445, 347 355. http://dx.doi.org/10.1016/j.scitotenv.2012.12.081

SINGH, D., FULEKAR, M.H. 2007. Bioremediation of Phenol Using Microbia Consortium in Bioreactor. Innovative Romanian Food Biotechnology, 1, 31-36.

VOLL, M.J., ISBISTER, J., ISAKI, L., MCCOMMAS, M., COLWELL, R.R 1978. Effects of microbial activity on aquatic pollutants. Annals of the New York Academy of Sciences, 298, 104-10. http://dx.doi.org/10.1111/j.1749 6632.1977.tb19257.x

WALKLEY, A., BLACK, I.A. 1934. An examination of the Degtjareff method for determining soil organic matter, and a proposed modification of the chromic acid titration method. Soil Science, 37, 29-38.

XU, R., OBBARD, J.P. 2004. Biodegradation of Polycyclic Aromatic Hydrocarbons in Oil-Contaminated Beach Sediments Treated with Nutrient Amendments. Journal of Environment Quality, 33, 861-867.

ZOLFAGHARI-BAGHBADERANI, A., EMTYAZJOO, M., POURSAFA, P., MEHRABIAN, S., BIJANI, S., FARKHANI, D., MIRMOGHTADAEE, P. 2012. 
Effects of three types of oil dispersants on biodegradation of dispersed crude oil in water surrounding two Persian gulf provinces. Journal of Environment Public Health, 2012, 1-8. http://dx.doi.org/10.1155/2012/981365 